\title{
Reciclado de aguas residuales en la fabricación de baldosas cerámicas
}

\author{
J.E. ENRIQUE' ${ }^{1}$, E. MONFORT ${ }^{1}$, G. BUSANI ${ }^{2}$, G. MALLOL ${ }^{1}$ \\ ${ }^{1}$ Instituto de Tecnología Cerámica.Asociación de Investigación de las Industrias Cerámicas. Universitat Jaume I. Castellón. (España) \\ ${ }^{2}$ Agenzia Regionale per la Prevenzione e I'Ambiente (ARPA). Modena (Italia)
}

Se ha estudiado el uso del agua en el proceso de fabricación de baldosas cerámicas y en particular, en las etapas de preparación de la pasta de los esmaltes y limpieza del equipo industrial y de la propia planta.Se ha realizado una revisión del consumo de agua y de los sistemas de reutilización de la misma en el proceso de fabricación de baldosas cerámicas y se ha estudiado con profundidad, a escala industrial, la reutilización del agua residual en el proceso y en particular el efecto de su reutilización sobre la emisión de contaminantes en las emisiones gaseosas y en los residuos sólidos.

Palabras clave: aguas residuales, baldosas cerámicas, reutilización.

\section{Water saving techniques in the spanish tile industry}

A study was conducted on the use of water in the ceramic tile manufacturing process, focussing on water requirements in body and glaze preparation and in washing production equipment and facilities. Water consumption and wastewater reuse systems in ceramic tile manufacture were reviewed. An in-depth, industrial scale study was performed of wastewater reuse in the manufacturing process, examining how wastewater reuse affected pollutant contents in gas emissions and solid waste.

Keywords: wastewater, ceramic tiles, recycling.

\section{EL AGUA EN EL PROCESO DE FABRICACIÓN DE BALDOSAS}

En todas las etapas del proceso de fabricación de baldosas cerámicas el agua juega un papel muy importante, realizando funciones específicamente tecnológicas, en las que actúa como materia prima, o en funciones auxiliares. Se ha realizado un análisis del proceso de fabricación determinando cuales son las etapas donde es necesaria la utilización del agua, que características debe tener y cuales son las etapas de las que resulta agua residual.

El caudal y las características del vertido pueden sufrir variaciones muy importantes con el tiempo, debido a que la mayor parte del vertido proviene de las operaciones de lavado de las líneas de esmaltado.

Desde el punto de vista químico el agua utilizada se caracteriza por la presencia de: Sólidos en suspensión arcillas, restos de fritas, silicatos insolubles en general, aniones en solución: sulfatos, cloruros, fluoruros, etc., metales pesados en solución y/o suspensión, boro en cantidades más o menos variables y trazas de materia orgánica vehículos serigráficos, colas y demás compuestos orgánicos utilizadas en las operaciones de esmaltado.

En la tabla I se detalla una composición tipo de vertido de las plantas de fabricación de baldosas cerámicas.

2 IMPLANTACIÓN DE

\section{WATER IN THE TILE MANUFACTURING PROCESS}

Water plays an important part in the ceramic tile manufacturing process, fulfilling specifically technological functions on being used as a raw material or material with auxiliary functions. The manufacturing process was therefore analyzed to determine in which process stages water was needed, establishing required water characteristics, and which process stages produced wastewater.

Wastewater flow rates and characteristics can exhibit very significant variations across time as most wastewater comes from washing operations in the glazing lines.

From a chemical point of view, the wastewater involved is characterized by the presence of:

- Suspended solids: clays, frit rests, insoluble silicates in general.

- Dissolved anions: sulfates, chlorides, fluorides, etc.

- Dissolved or suspended heavy metals.

- More or less variable quantities of boron.

- Traces of organic matter: screen-printing vehicles, glues and other organic compounds used in glazing operations.

Table I presents a standard wastewater composition produced in glazed tile manufacture. 


\section{SISTEMAS DE REUTILIZA- CIÓN DE AGUAS RESIDUALES}

TABLA I.- ANÁLISIS QUÍMICO MEDIO DE AGUAS RESIDUALES SIN DEPURAR. ARISING IN GLAZED TILE MANUFACTURE.
TABLE I.- AVERAGE CHEMICAL ANALYSIS OF NON-TREATED WASTEWATER

\section{IMPLEMENTATION OF WASTEWATER REUSE SYSTEMS}

\begin{tabular}{|c|c|c|c|}
\hline Substance & $\begin{array}{c}\text { Variation } \\
\text { interval }\end{array}$ & Substance & $\begin{array}{r}\text { Variation } \\
\text { interval } \\
\end{array}$ \\
\hline $\mathrm{PH}$ & $7-9$ & Boron $(\mathrm{mg} / \mathrm{l})$ & $1-10$ \\
\hline Suspended matter $(\mathrm{mg} / \mathrm{l})$ & $1000-20000$ & Calcium (mg/l) & $5-500$ \\
\hline Settleable matter $(\mathrm{mg} / \mathrm{l})$ & $5-30$ & Magnesium (mg/l) & $10-100$ \\
\hline Chlorides (mg/l) & $100-700$ & Aluminium (mg/l) & $<2$ \\
\hline Sulfates (mg/l) & $100-500$ & $\operatorname{Iron}(\mathrm{mg} / \mathrm{l})$ & $<0.5$ \\
\hline Fluorides (mg/l) & $<2$ & Zinc (mg/l) & $<2$ \\
\hline COD (mg/l) & $150-1000$ & Lead (mg/l) & $<5$ \\
\hline BOD5 (mg/l) & $50-400$ & & \\
\hline
\end{tabular}
facturing process.
Growing water demands for industrial use and stricter pollution control regulations have led to a constant rise in industrial water supply and effluent treatment costs. This led to considering the possibility of wastewater reuse in the same manu-

The amounts of reusable wastewater were determined for a cación.

Se ha determinado para una planta industrial tipo cantidades que se pueden recircular, así como en que etapa del proceso se podrán recuperar. La recirculación de las aguas residuales en el propio proceso presenta problemas de diversa índole que se deben resolver adecuadamente. Pero las ventajas que ofrece el reciclado de aguas residuales son notables:

- Ahorro del consumo de agua.

- Menor cantidad de vertidos para eliminar.

- Menor coste de tratamiento de aguas, dado que suele ser más económico tratar el agua para recircular que para verter, pues los límites de los elementos en suspensión y / o disolución vienen fijados por la alteración que producen en la etapa receptora del reciclado y no por la Legislación que suele ser más estricta.

Por todo esto, es importante conocer los requisitos cualitativos del agua utilizada a lo largo del proceso para saber el tratamiento al que deben de ser sometidas las aguas residuales antes de su posible reutilización. Se han estudiado los requisitos cualitativos del agua en cada etapa del proceso de fabricación de baldosas y se ha comprobado que, en el caso de la utilización del agua en la molienda por vía húmeda, las cantidades de agua a utilizar son destacables y las comprobaciones aconsejables a la hora de plantear la sustitución del agua industrial por el vertido, son las posibles alteraciones de la reología de la barbotina de pasta y la aparición de eflorescencias.

Conocidos los requisitos cualitativos del agua en cada etapa del proceso, si el agua usada se destina al proceso de preparación de pastas, en principio, no será necesario realizar ningún tratamiento, únicamente se construirá una balsa de homogeneización para asegurar dentro de lo posible, una constancia de sus características. Por otra parte si se quiere utilizar el agua en la limpieza de las instalaciones, la calidad de esta deberá ser superior, para lo cual se realizará un tratamiento de sedimentación y posterior aireación, con o sin posterior tratamiento químico para eliminar los problemas de olores.

El calculo del agua residual a añadir al molino se realiza mediante un balance de materia.

\section{EFECTOS DE LA REUTILIZACIÓN DE LAS AGUAS RESIDUALES SOBRE LAS EMISIONES ATMOSFÉRICAS Y SOBRE LOS RESIDUOS}

Como se ha comentado en apartados anteriores, es muy importante si se pretende llevar a cabo acciones de reciclado, tener en cuenta que efectos puede causar dicha acción sobre la calidad del producto final y sobre el entorno desde un punto de vista medioambiental. standard glazed tile manufacturing facility, as well as the process stages in which wastewater could be reused. Wastewater reuse in the same manufacturing process poses various problems that need to be adequately solved. However, wastewater reuse also entails significant advantages:

- Savings in water consumption.

- Less waste to be disposed of.

- Lower wastewater treatment costs, as it is usually cheaper to treat water for reuse than for disposal, since the limits of suspended and/or dissolved elements are fixed by the alteration to the process stage in which reuse occurs, and not by legislation requirements, which tend to be much stricter.

It is therefore important to identify the qualitative requirements of the water used throughout the process in order to know what wastewater treatment is needed prior to possible reuse.

The qualitative requirements of the water used in each tile manufacturing stage were determined. It was found that in the wet milling stage large quantities of wastewater can be used instead of industrial water, if suitable controls are implemented to monitor possible changes in the rheology of the body slip and appearance of efflorescence.

Having established qualitative water requirements in each process stage it was found that if wastewater were to be reused in body preparation, in principle no pretreatment would be needed other than a homogenization tank to ensure the most consistent possible water characteristics for body preparation. If the wastewater were to be reused for washing facilities however, water quality would need to be higher, so that a settler would be required, followed by aeration with or without subsequent chemical treatment for suppressing smells.

The wastewater to be added to the mill needs to be suitably proportioned. This can be readily performed by means of a mass balance.

\section{EFFECTS OF WASTEWATER REUSE ON AIR EMISSIONS AND SOLID WASTE}

As indicated above, in wastewater reuse it is very important to take into account the effects that such reuse can have on final product quality and on the environment.

Studies performed by the Instituto de Tecnología Cerámica (ITC) have shown the feasibility of reusing wastewater as a raw material in body preparation in the same manufactu- 
En estudios realizados por el Instituto de Tecnología Cerámica (ITC), se ha demostrado la viabilidad de reciclar las aguas residuales como materia prima en el propio proceso de fabricación en la fase de preparación de pastas comprobándose que la aplicación controlada de estos sistemas de reciclado no produce alteraciones significativas en las variables de proceso ni sobre la calidad de los productos fabricados (3).

En estos sistemas de reciclado el agua residual en su mayor parte se elimina por evaporación en el proceso de secado por atomización y los materiales en suspensión y en disolución presentes en las mismas se supone que se incorporan al producto acabado (1) (2).

En la figura 1 se muestra un esquema de una planta de tratamiento de aguas residuales industriales, con el que se puede lograr un vertido cero de aguas residuales, reutilizándolas como materia prima en la preparación de pastas.

En esta figura 1 se observa que el agua se recicla sin ningún tipo de depuración previa en la preparación de pastas, esto es así en la mayor parte de instalaciones, simplemente efectuando una homogeneización previa de la misma, y controlando su densidad para no sobrepasar los contenidos en sólidos permisibles obtenidos en ensayos previas. Con este sistema es necesario modificar ligeramente el contenido en desfloculante a adicionar a la suspensión para obtener el comportamiento reológico deseado.

Por otra parte, en la figura 1 también puede observarse que en el caso de que exista un exceso de agua residual sobre el agua consumido en la preparación de pastas, parte de la misma puede reutilizarse con un tratamiento previo de depuración química en otras operaciones de la instalación: limpieza de la planta, como agua para depuración de gases en los filtros vía húmeda, etc. En este caso también tras el ciclo de reciclado el agua se incorporará a la preparación de pastas y se puede lograr fácilmente un vertido cero de aguas residuales (4)(5).

No obstante, uno de los temas que no ha sido tratado anteriormente y que sin embargo tiene gran importancia es la evaluación del posible incremento del impacto medioambiental de las instalaciones al reutilizar sus aguas residuales en la preparación de pastas. Se supone que los efectos principales se producirán sobre las emisiones y sobre la composición de los residuos generados en el propio proceso (restos de piezas crudas y restos de piezas cocidas).

En los apartados siguientes se trata por separado la evaluación de los posibles efectos de la acción de reciclado sobre las emisiones atmosféricas generadas durante el proceso de fabricación y sobre la composición de los residuos generados en el propio proceso.

Para ello, se ha realizado un trabajo experimental en un proceso de fabricación de revestimiento poroso por monococción que recicla las aguas residuales y los fangos, según el esquema de la figura 1, además de los residuos crudos generados en el propio proceso, incorporándolos a la composición el soporte. ring process. The controlled application of these recycling systems was found to produce no significant changes in process variables or in the quality of the final product (3).

In these recycling systems, most of the wastewater is eliminated by evaporation in spray drying, and the suspended and dissolved materials contained in the wastewater are assumed to be incorporated in the final pro$\operatorname{duct}(1)$ (2).

Fig. 1 depicts the schematic of an industrial wastewater treatment system in which zero wastewater emission can be achieved on reusing the arising wastewater as a raw material in body preparation.

In this figure it can be observed that the wastewater is reused directly in body preparation without any type of pretreatment. This is the case in most facilities in which the wastewater is simply homogenized, controlling density so as not to exceed the admissible solids contents determined in preceding tests. With this system it is necessary to slightly modify the deflocculant proportion to be added to the suspension to achieve the desired rheological behaviour.

On the other hand, it can also be observed in Fig. 1 that when the arising wastewater exceeds water consumption in body preparation, a part of the wastewater can be reused after chemical treatment in other operations: for washing, gas scrubbing in wet filters, etc. After such recycling, the arising wastewater can again be used in body preparation and zero wastewater emission can readily be achieved (4) (5).

However, one of the issues as yet not addressed, and nonetheless of great importance is the assessment of the possible increased environmental impact on reusing wastewater in body preparation. It is assumed that this would mainly affect the resulting air emissions and composition of the solid waste (green and fired tile scrap) arising in the manufacturing process.

The following sections will separately assess the possible effects of wastewater reuse on air emissions and on the composition of the solid waste produced in glazed tile manufacture.

The experimental study was conducted at a porous singlefire wall tile manufacturing facility, at which wastewater and sludge were recycled according to the schematic depicted in Fig. 1, while the arising green scrap was also reused in the same process by being added to the body composition.

\subsection{Effect of industrial wastewater reuse on air emissions}

The study first addressed the pollutants present in the gas emissions produced in spray drying and firing, as these are the key tile manufacturing processes.

Boron and lead, which are not present in the body raw materials, were used as tracing elements of the reused wastewater.

These elements (boron and lead) come from the water used to wash the glaze preparation and application facili- 


\subsection{Efecto de la reutilización de las aguas industriales sobre} las emisiones atmosféricas

En una primera parte del estudio realizado se abordó el estudio de los contaminantes presentes en las emisiones gaseosas generadas en los procesos de secado por atomización y cocción, por tratarse de las etapas más significativas en el proceso de fabricación de baldosas cerámicas.

Como elementos trazadores del agua residual en el estudio de la etapa de secado por atomización se han elegido dos elementos que no están presentes en las materias primas del soporte: boro y plomo.

Estos elementos (boro y plomo), provienen del agua de limpieza de las secciones de preparación y aplicación de esmaltes. La mayor parte de estos elementos queda retenido en los gránulos de atomizado y el resto, que es el que se detecta en las emisiones, se arrastra con el agua que se evapora en el secado por atomización (6).

Por ello se han designado como elementos trazadores ya que en el estudio de las emisiones en el proceso de secado por atomización determinaran si en el caso de llevar a cabo procesos de reciclado estos compuestos quedan retenidos en la pasta o son emitidos directamente a la atmósfera.

La presencia del boro y plomo en las aguas residuales es debida a la elevada solubilidad que presentan en el agua, de forma que si quedan retenidos en este medio y más tarde estas aguas se reciclan sin someterlas a ningún tipo de depuración, pueden ir acumulándose en la composición inicial, generando algún tipo de impacto medioambiental sobre el entorno.

Por ello, el efecto más importante en este caso, era el posible aumento de la concentración de boro y plomo en las emisiones generadas en los procesos de secado por atomización.

En la tabla II, se muestran los intervalos de variación de la concentración obtenidas de dichos elementos:

Como puede observarse, los valores de la concentración de boro y plomo son bajos, debido a que la concentración de estos elementos en el agua de limpieza utilizada para la preparación de la barbotina es baja, ya que su presencia se debe a la disolución de estos elementos presentes en los restos de esmaltes en el agua de limpieza.

En cuanto al estudio de las emisiones atmosféricas generadas en el proceso de cocción, los datos de la naturaleza y concentración de las sustancias, corresponde únicamente a la chimenea de humos, que es la que puede necesitar la depuración de las sustancias contaminantes.

En la tabla III se detallan las sustancias estudiadas y determinadas en las emisiones atmosféricas del horno. En esta etapa el boro presente en las emisiones proviene principalmente del agua presente en la pieza a la entrada del horno, que se evapora en las primeras etapas de la operación de cocción. Esta agua ha quedado en la pieza tras el secado del soporte o ha sido incorporada al soporte y/o esmalte durante la operación de esmaltado.

Los valores de la concentración de boro son reducidos, debido a que la concentración de este elemento en el agua de limpieza es baja.

El contenido en plomo de la corriente es bastante reducido y procede fundamentalmente de vaporizaciones de aquellos esmaltes, actualmente minoritarios, en los que se emplea este elemento en su composición.
TABLA II.- CONCENTRACIÓN DE LAS SUSTANCIAS PRESENTES EN LAS EMISIONES ATMOSFÉRICAS GENERADAS EN EL PROCESO DE SECADO POR ATOMIZACIÓN.

TABLE II.- CONCENTRATIONS OF SUBSTANCES PRESENT IN SPRAY DRYING AIR EMISSIONS.

\begin{tabular}{|l|c|c|c|}
\hline Substance & $\begin{array}{c}\text { Variation } \\
\text { interval }\end{array}$ & Substance & $\begin{array}{c}\text { Variation } \\
\text { interval }\end{array}$ \\
\hline $\mathrm{Ps}\left(\mathrm{mg} / \mathrm{Nm}^{3}\right)$ & $150-1500$ & $\mathrm{~B}\left(\mathrm{mg} / \mathrm{Nm}^{3}\right)$ & $<0.3$ \\
$\mathrm{NO}_{\mathrm{x}}(\mathrm{ppm})$ & $3-15$ & $\mathrm{Cl}\left(\mathrm{mg} / \mathrm{Nm}^{3}\right)$ & $1-5$ \\
$\mathrm{CO}(\mathrm{ppm})$ & $1-15$ & $\mathrm{~Pb}\left(\mathrm{mg} / \mathrm{Nm}^{3}\right)$ & $<0.15$ \\
$\mathrm{CO}_{2}(\%)$ & $1.5-4$ & & \\
\hline
\end{tabular}

ties. The greater part of these elements is retained in the spray-dried granules and the remainder, which is detected in the air emissions, is borne along with the evaporating water in spray drying (6).

These elements were chosen as tracing elements since finding them in the spray-drying emissions would indicate whether the compounds are incorporated into the body or are directly released into the air in wastewater reuse.

Thus the most important effect in this case was the possible increase in boron and lead concentrations in spraydrying emissions.

Table II details the variation intervals for the element concentrations found.

Boron and lead concentrations are low, as their concentrations in the cleaning water used for preparing the slip are low. Their presence stems from the dissolution of the boron and lead that is present in glaze rests in the cleaning water.

With regard to the study of air emissions produced in firing, the data on the nature and concentrations of these substances correspond to the exhaust stack, as this is the only stack at which pollutant cleaning might be needed.

Table III lists the substances studied and determined in kiln air emissions. In this process stage the boron present in the emissions comes mainly from the water contained in the tile on entering the kiln, which is evaporated in the first firing stages. This water has remained in the tile after drying or has been incorporated into the body and/or glaze during the glazing operation.

Boron concentrations are very low, as the boron concentration in the cleaning water is very low.

The stream's lead content is quite low and mainly comes from the vaporization of glazes containing this element in their composition, currently quite a minor group of glazes.

TABLA III.- CONCENTRACIÓN DE LAS SUSTANCIAS PRESENTES EN LA CHIMENEA DE HUMOS

TABLE III.- CONCENTRATIONS OF SUBSTANCES PRESENT IN THE EXHAUST STACK

\begin{tabular}{|l|c|c|c|}
\hline Substance & $\begin{array}{c}\text { Variation } \\
\text { interval }\end{array}$ & Substance & $\begin{array}{c}\text { Variation } \\
\text { interval }\end{array}$ \\
\hline $\mathrm{Ps}\left(\mathrm{mg} / \mathrm{Nm}^{3}\right)$ & $5-50$ & $\mathrm{~B}\left(\mathrm{mg} / \mathrm{Nm}^{3}\right)$ & $<0.5$ \\
$\mathrm{NO}(\mathrm{ppm})$ & $15-60$ & $\mathrm{Cl}\left(\mathrm{mg} / \mathrm{Nm}^{3}\right)$ & $20-90$ \\
$\mathrm{CO}(\mathrm{ppm})$ & $1-15$ & $\mathrm{~Pb}\left(\mathrm{mg} / \mathrm{Nm}^{3}\right)$ & $<0.15$ \\
$\mathrm{CO}(\%)$ & $1.5-4$ & $\mathrm{~F}\left(\mathrm{mg} / \mathrm{Nm}^{3}\right)$ & $5-40$ \\
$\mathrm{SO}_{2}\left(\mathrm{mg} / \mathrm{Nm}^{3}\right)$ & $<10$ & & \\
\hline
\end{tabular}




\subsection{Efecto de la reutilización de las aguas industriales sobre los residuos generados}

En este trabajo también se estudiaron los posibles efectos que genera la recirculación de las aguas residuales, sobre los residuos que se obtienen como consecuencia del proceso de fabricación.

En primer lugar cabe destacar la existencia de dos tipos de residuos obtenidos directamente del proceso, por un lado todos los residuos crudos (piezas rotas de prensado y secado) y por otro lado los residuos generados tras la etapa de cocción (restos de piezas con defectos, piezas rotas, etc).

La gestión de estos dos tipos de residuos es diferente, mientras que los residuos crudos se reciclan actualmente en el proceso de preparación de pastas, sin necesitar ningún tipo de acondicionamiento, los residuos o restos de piezas obtenidos tras el proceso de cocción son gestionados como inertes o empleados por terceros como materiales de relleno en construcción.

Para la realización del estudio del efectos sobre la etapa de cocción, se ha elegido el boro como elemento trazador, por ser uno de los elementos más significativos, debido a su elevada solubilidad en agua y su posible acumulación en el proceso al llevar a cabo el reciclado de las aguas residuales. Además es un elemento que se encuentra presente en cantidades tales que permiten por análisis químico cuantificar su contenido en todas las corrientes estudiadas (7).

Inicialmente se determinó la cantidad de boro en las materias primas de los esmaltes, una vez determinada esta cantidad se procedió a la toma de muestras durante dos semanas de producción habitual.

A partir de los valores obtenidos en distintos análisis químicos y realizando un balance de materia al proceso se han obtenido los caudales másicos de compuestos de boro en todas las corrientes.

Los valores de los caudales másicos se han expresado en miligramos de boro por kilogramo de materia prima del soporte procesadas.

Los caudales másicos de boro, con la base de cálculo indicada anteriormente, obtenidos de forma experimental y mediante cálculos se detallan en la tabla IV.

De acuerdo con estos resultados los elementos presentes en las aguas residuales en suspensión y en disolución se incorporán al producto cocido, quedando inertizados en el mismo. El único posible impacto medioambiental sería la posible solubilidad de los residuos cocidos obtenidos (pieza fuera de especificación o norma, roturas, etc.), pero en este proceso estos residuos también se incorporan a la fase de preparación de pastas como chamota, con lo que el incremento en el impacto mediombiental de la reutilización de aguas puede considerarse prácticamante insignificante.

\section{CONCLUSIONES}

De acuerdo con los resultados obtenidos en el estudio realizado de las emisiones en el proceso de secado por atomización y en la etapa de cocción y los resultados obtenidos del balance másico del boro en diferentes corrientes, se ha detectado que los compuestos de boro quedan incorporados mayoritariamente en el producto acabado, inertizados en el mismo.

Por ello, el reciclado de aguas residuales de acuerdo con el esquema propuesto en este trabajo se ha observado que produce un incremento del impacto medioambiental insignifican-

\subsection{Effect of wastewater reuse on the arising solid waste.}

The study also addressed the possible effects of wastewater reuse on the arising solid waste in the manufacturing process.

Two types of solid waste are basically produced in the process: green scrap (broken pieces from pressing and drying), and fired scrap (defective or broken tiles etc.).

Management of these two types of waste is different. Green scrap is reused directly in the body preparation process without pretreatment, whereas fired scrap is disposed of as inert waste or used by third parties as a filler in building construction.

In order to carry out a study on the effects of wastewater reuse on the firing stage, boron was used as a tracing element on being one of the most significant elements, owing to its high water solubility and possible accumulation in the wastewater reuse process. Boron is moreover an element that is found in sufficient quantities to allow quantifying its presence in all the studied streams by chemical analysis (7).

Boron contents were first determined in the glaze raw materials, subsequently sampling during two weeks of standard production.

Using the values obtained in the various chemical analyses, and drawing up a mass balance of the process, the mass flow rates of the boron compounds were found for all the streams.

Mass flow rates are expressed in $\mathrm{mg}$ boron $/ \mathrm{kg}$ processed body raw material.

The resulting boron mass flow rates, obtained by using the calculation indicated with experimental data and relevant calculations, are set out in Table IV.

The results show that the dissolved or suspended elements present in the reused wastewater are mainly incorporated into the fired product where they are immobilized. The only possible environmental impact would be the possible solubility of the resulting fired scrap (non-conforming to standard or broken tiles, etc.), but in this process such waste can also be reused in the body preparation stage as grog, so that the environmental impact of wastewater reuse can be considered practically negligible.

\section{CONCLUSIONS}

In accordance with the results obtained in the study of the arising air emissions in spray drying and firing, and the data from the mass balance of boron in the various streams, it was verified that most boron compounds were incorporated in the finished product, where they were immobilized.

TABla IV.- CAudales MÁSICOS DE BORO EN DIFERENTES CORRIENTES. TABLE IV.- BORON MASS FLOW RATES IN DIFFERENT STREAMS.

\begin{tabular}{|l|c|}
\hline STREAM & BORON (mg/kg body) \\
\hline Waste reused in body preparation & \\
(wastewater+sludge+glaze rests+green scrap) & 225 \\
Spray-dried powder and unglazed green tile & 224.7 \\
Spray dryer emissions & 0.3 \\
Glaze raw materials & 740 \\
Unfired glazed tiles & 739.7 \\
Fired glazed tiles & 739.1 \\
Firing kiln emissions & 0.6 \\
\hline
\end{tabular}


te, si se mantiene la emisión de partículas de los secaderos por atomización por debajo de $50-75 \mathrm{mg} / \mathrm{Nm}^{3}$, y si además se reciclan en el mismo proceso los residuos crudos y cocidos del mismo.

Por todo ello, desde el punto de vista económico y medioambiental la implantación de un sistema de reciclado de las aguas residuales y de residuos en el propio proceso de fabricación, constituye la mejor tecnología disponible para tratar esas corrientes residuales.

\section{BIBLIOGRAFÍA / REFERENCES}

1 A. Blasco, F. Ginés, J.C. Jarque, E. Monfort. Adición de fangos reciclados a composiciones de pavimentos y revestimientos cerámicos (I). Técnica Cerámica, 195, 470-483, (1991)

2 A. Blasco, F. Ginés, J.C. Jarque, E. Monfort. Adición de fangos reciclados a composiciones de pavimentos y revestimientos cerámicos (y II). Técnica Cerámica, 196, 578-585, (1991)

3 A. Blasco,. et al. Tratamiento de emisiones gaseosas, efluentes líquidos y residuos sólidos de la industria cerámica. Castellón. Ed.. AICE-ITC, 1992.
Thus, in wastewater reuse according to the system proposed in this work, it was found that there was a negligible environmental impact if spray dryer dust emissions were kept below $50-75 \mathrm{mg} / \mathrm{Nm}^{3}$, and if green and fired scrap was also reused in the same process.

From an economic and environmental viewpoint, the implementation of a wastewater reuse system, with reuse of the arising green and fired scrap, therefore represents the Best Available Technique for treating these waste streams.

4 J.E. Enrique, E. Monfort, F. Ferrando, F. Negre,. Elimination of boron from waster produced in the ceramic industry. 7 Mediterranean Congress of Chemical Engineeringt. Barcelona. (1996).

5 P. Mazzali. L'inquinamento atmosferico. Bolonia:Ed. Pitagora, 1989.

6 G. Busani, C. Palmonari, G. Timellini. Piastrelle ceramiche $\mathcal{E}$ ambiente Modena:Edicer. (1995)

7. F. J. López, E. Giménez, F. Hernández. Analitical study on the determination of boron in environmental water samples. Fresenius J. Anal. Chem., 346, 984987, (1993). 